\title{
Fate, Divine Will and Narrative Concept in the
} Homeric Epics

\section{Efstratios Sarischoulis}

\section{(2) OpenEdition \\ 1 Journals}

\section{Electronic version}

URL: http://journals.openedition.org/mythos/464

DOI: $10.4000 /$ mythos. 464

ISSN: 2037-7746

\section{Publisher}

Salvatore Sciascia Editore

\section{Printed version}

Date of publication: 1 December 2016

Number of pages: 81-105

ISBN: 978-88-8241-476-4

ISSN: 1972-2516

\section{Electronic reference}

Efstratios Sarischoulis, «Fate, Divine Will and Narrative Concept in the Homeric Epics », Mythos

[Online], 10 | 2016, Online since 24 September 2019, connection on 28 September 2019. URL : http:// journals.openedition.org/mythos/464; DOI : 10.4000/mythos.464 


\section{Fate, Divine Will and Narrative Concept in the Homeric Epics ${ }^{1}$}

\section{Efstratios Sarischoulis}

\section{Abstract}

Human action and its consequences in the Iliad and the Odyssey are determined neither by fate nor by the gods. The reconstruction of the concept actually depicted in Homer confirms no conflict between fate and the gods as co-existing forces but reflects the personal motives of active agents, both human and divine, as the basis that underpins the sequence of events in both epics. Nature and individual purposes of each and every active agent, personal desires and aims harboured by human and divine actors shape these motives in a world that perceives life as a path leading to death with no preordained events but as a compound of actual alternatives. In this world every single action is attributed to choices, has its reasons, elicits reactions or rather consequences. As a result, the particular active agent takes resposibility for each choice he makes and shapes his own future. Various forms of divination as well as the perception of omens confirm this conclusion, as predictions in the Homeric epics do not point out predetermined events but motives, decisions and actions of the human actor involved.

\section{Keywords}

Homer - Fate - Gods - Decision

\section{Zusammenfassung}

Menschliches Handeln und dessen Folgen sind in der llias und der Odyssee weder vom Schicksal noch von den Göttern bestimmt. Die Rekonstruktion des bei Homer tatsächlich dargestellten Konzepts bestätigt keinen Konflikt zwischen Schicksal und den Göttern als mitbestimmenden Mächte, sondern spiegelt die persönlichen Motive von handelnden Figuren, sowohl menschlichen als auch göttlichen, als Grundlage für die Entwicklung der Handlung beider Epen wider. Natur und individuelle Zwecke einer jeden handelnden Figur, persönliche Wünsche und Ziele menschlicher und göttlicher Akteure prägen diese Motive in einer Welt, die das Leben als einen Weg wahrnimmt, der ohne vorherbestimmte Ereignisse sondern als eine Zusammensetzung von tatsächlich bestehenden Alternativen zum Tode führt. In dieser Welt ist jede einzelne Aktion auf Entscheidungen zurückzuführen, hat ihre Gründe, löst Reaktionen bzw. Konsequenzen aus. Daher trägt die jeweilige handelnde Figur die Verantwortung für jede getroffene Entscheidung und gestaltet ihre eigene Zukunft. Diverse Arte von Weissagungen wie auch die Wahrnehmung von Vorzeichen bestätigen diese Schlussfolgerung, denn die Vorhersagen in den Epen Homers weisen nicht auf vorbestimmte Ereignisse hin, sondern auf Motive, Entscheidungen und Handlungen der beteiligten menschlichen handelnden Figur.

\section{Schlüsselworte}

Homer • Schicksal • Götter • Entscheidung • Handeln

\section{The Problem ${ }^{1}$}

$\mathrm{F}$

Ior centuries, Homer's various interpreters assumed the existence of a struggle between two conflicting forces that affect both the course of specific events and the development of the action in Iliad and Odyssey. ${ }^{2}$ One of these forces is the notorious power of

1 I am much indebted to Henry Heitmann-Gordon for translating the original German version of this article into English.

2 A collection of literary analyses that cover a selection of relevant views and publications from the 20th century and provide an overview of prominent hypotheses and their counterpoints can be found in SARISCHOULIs 2008c. 
fate ${ }^{3}$ the other the power of the gods. Numerous attempts have been made to explain the relationship between these forces in hierarchical terms. All of them, however, have failed, for the following reasons:

1. Scholars based their interpretations of Homer on their own conceptions of fate and thus postulated a concept of "Homeric fate".

2. Interpretations considered, without reservation, the gods of the Homeric epics to be more or less omnipotent.

Despite the differences of opinion as to which force actually determined the events, all past interpretations agree on two basic points:

1. In each concrete scenario, human actors can be considered independent only within limits, if at all. ${ }^{4}$

2. The contradiction between the two, allegedly co-determining, forces, whose hierarchy is subject to the interpreter's inclination, ${ }^{5}$ continues to persist and requires further detailed explanation.

This contradiction ${ }^{6}$ may well be irresolvable. ${ }^{7}$ Instead, a different approach is advisable: on

3 The concept of "Homeric fate" has caused a certain level of confusion, especially among renowned scholars of Homer. A prominent example is provided by SCHADEwALdT 1966, 108 with n. 1, who considers the death of Hector as "[ein] in seinem Wesen angelegtes, unabänderliches Teil", but remains evasive on the function of $\mu o \tilde{\varrho} \alpha$ : "Als die allgemeine regelnde Macht im Grundbestand all dessen, was ist, ist Moira göttlich und eine Gottheit, aber in ihrer Allgemeinheit eben kein Gott von umrissenem Charakter".

4 In this vein Voigr 1934 leaves hardly any space for independent action by humans in Homer. Based on the same view, SNell 1975, 13-29 (= Chap. 1: "Die Auffassung des Menschen bei Homer") developed his concept of so-called "Homeric man". In his view, human action is based in the workings of the omnipotent gods, of inevitable fate, or a combination of the two. Since SNELL's concept has fundamentally shaped the terminus technicus of "Homeric man", the term should be discarded entirely; cf. SARISCHOUlis 2008a, 141-50 (= Chap. II.3.1: "Der 'homerische Mensch"). Another important contribution to the discussion about Homeric concepts of action is provided by LesKY 1961, who highlighted motivation as a fundamental aspect of the narrative in both Iliad and Odyssey. Unfortunately, he was not able to solve the controversy; cf. the detailed criticism in $\mathrm{S}_{\mathrm{A}-}$ RISCHOUlis 2008a, 151-160 (= Kap. II.3.2: "Zu (Leskys 'doppelter') Motivation menschlichen Handelns") and SARISChOULIS 2008b, passim. Last, but not least, one must also mention the important study by SснмiтT 1990, that has provided numerous accurate interpretations of smaller-scale problems. But by focussing his complex and precise discussion on individual passages, he ultimately causes great confusion and fails to pull the threads together into an interpretative concept that is unified, flexible, and simple enough to allow an understanding of Homer's narrative mode as a whole; cf. the criticism in SARISCHOULIs 2008a, 151 n. 602 and 166 n. 640, as well as SARISCHOUlis 2008b, 14-15 et passim.

5 Krause 1949, 10-52, considers $\mu$ oĩ $\alpha$ as largely subordinate to Zeus; also Bianchi I953, 36, describes $\mu$ oị $\alpha$ and $\alpha \tilde{i} \sigma \alpha$ as subordinate to Zeus, and argues that expressions such as $\Delta$ iò $\varsigma \tilde{i} \sigma \alpha$ were mere conventional phrases.

6 Cf. e.g. Eberhard 1923, 11: "Wir müssen hier die merkwürdige Tatsache feststellen, dass in Ilias und Odyssee das Schicksal (sc. $\mu$ oĩo $\alpha$ und $\alpha$ ĩ $\sigma \alpha$ ) bald über, bald unter oder neben den Göttern steht." ["We must here note the strange fact that Iliad and Odyssey sometimes portray fate (sc. $\mu$ oĩ $\alpha$ and $\alpha \tilde{\tau} \sigma \alpha)$ as superordinate, sometimes as subordinate and sometimes on the same level as the gods."]; in this vein, ENGEL 1926, 93-94, argues that Polyphemos' prayer to Poseidon (Od. 9.528-535) after being blinded by Odysseus expresses his conviction that the gods are subordinate to Moira. ENGEL notes: "Das Gebet hält also den Fall wohl für möglich, dass es außerhalb der göttlichen Macht liegen könne, die Heimkehr zu verhindern, weil es vom Schicksal anders festgelegt ist, und bittet in diesem Fall die ersehnte Heimkehr wenigstens hinauszuschieben."

7 Cf. PöTsCher 1960, 24 with n. 73 and further literature, who considers "eine Lösung im Sinne einer Über- oder Unterordnung als unmöglich.” 
the one hand, one should try to determine the exact content of the so-called terms of fate ${ }^{8}$ in the Homeric epics and focus on the actual connotations expressed by these terms; on the other hand, the nature and function of divine power in the Iliad and the Odyssey should be investigated in detail, but without postulating omnipotence a priori. It is thus necessary to analyse closely the thoughts and ideas actually expressed in the Homeric epics in order to reconstruct the concept actually described by Homer.

\section{Conflict and Consequence}

$\mathrm{F}$ rom antiquity to modern scholarship, "fate" in Homer has always been tacitly postulated or implied in every scholion and every interpretation. So-called "Homeric fate" is accorded such supreme power" that one delights in speaking of preordained sequences of action on every possible occasion. The inevitability of the events to come thus seems completely without question. Various interpreters, however, consider this power of fate to be contrasted with the will of the gods, with divine premeditation and action, which is itself a force that is often likewise referred to as omnipotent.

Hence at least one omnipotent force is always active, prefiguring the sequences of events in the short-, mid- and long-term. Under generally undisclosed circumstances, occasions can arise in which events are shaped by both of these omnipotent forces, sometimes in cooperative harmony, sometimes in opaque dissonance. The hierarchical order of their relationship usually remains unclear in these scenarios.

These omnipotent forces may cooperate or clash, for humans the consequences remain much the same. Human action is not real action; their plans and activities are either predetermined or dashed to pieces by one or the other of these omnipotent forces that can appear either as cooperating actors or as vicious antagonists. ${ }^{10}$ Restricted to a role as a purely virtual agent, man can simply play along in this scheme, can participate in this "game" with its predetermined outcome, can observe what happens to himself.

8 A rough overview of the contexts in which the so-called terms of fate occur in Homer is provided by the col-

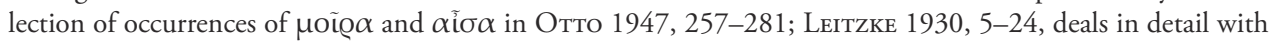
the occurrences of $\mu$ oi $\alpha$; KRAUSE 1936, 143-152 contributes to the reconstruction of semantics and also takes account of etymology; GREENE 1944, 10-28, deals with a number of occurrences and considers older views and publications that study the etymological derivation of the concepts of fate, App. 4, 401-402; cf. also LUTHER 1954, 54-63. NiLsson 1967-1974, I 361-368, has also investigated the contexts in which certain terms and phrases are used that allegedly express the so-called "Homeric fate"; Erbse 1986, 274-293, has studied a limited selection of occurrences of these so-called terms of fate and thus misses various nuances of meaning.

9 Cf. Schrade 1952, 128: "Die homerische Moira ist durchaus unerforschlich zuteilende Macht, gewaltig in ihrer Kraft: krataié."

10 SNELL 1928, 24 therefore compares the actions performed by so-called "Homeric man" with the actions performed by animals: "Wie dem Tier keine eigene Wahl bleibt, wie es auf jeden Reiz mit dem schicksalhaft bestimmten Handeln antworten muss, wie auch jede Größe und jedes Opfer, zu dem ein Tier sehr wohl imstande ist, nur unter der Notwendigkeit steht, so sind auch die homerischen Menschen ganz gebunden an das Schicksal, an die Götter. Das Wissen greift noch nicht das eigene Innere an. Die ganze Welt ist Außenwelt und der homerische Mensch ist problemlos." 


\section{The so-called terms of fate}

$\mathrm{W}$

hether this view corresponds to Homer's actual depiction or whether it has been shaped by Homer's interpreters and thus reflects their understanding of fate, can be determined by investigating the so-called Homeric terms of fate ( $\mu$ oĩ $\alpha, \mu o ́ \varrho o \zeta$,

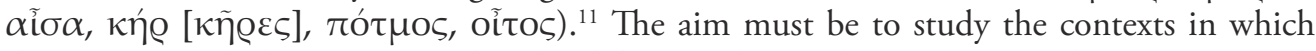
these terms and phrases are employed, while considering the associations they carry in each instance. $^{12}$

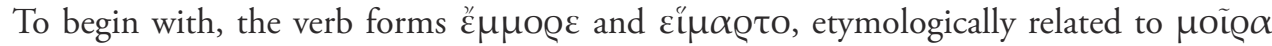
and $\mu$ ógos, ${ }^{13}$ express the concept of receiving something as an allotted share of a specific

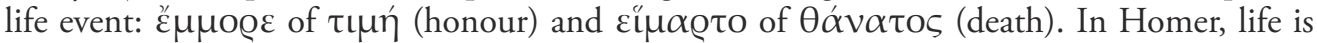
considered as a sequence of allotments in such life events. The final allotment, death, is always expressed by means of the pluperfect cil $\mu \alpha \varrho \tau$, since participation in death is the single inevitable constant in the existence of each living creature. One might even say that its precise circumstances have already been predetermined at the moment of birth. The terms $\pi \dot{\varepsilon} \pi \varrho \omega \tau \alpha \mathrm{t}$ and $\pi \varepsilon \pi \varrho \omega \mu \varepsilon \dot{v}$ os, which occur only in the Iliad, further strengthen the claim that a concept of predetermined death is found in Homer. Unfortunately this claim is simultaneously called into question by the fact that the gods can repeatedly protect a human from death, ${ }^{14}$ without being able to free him from the burden of mortality entirely. In Homer's narratives, death is thus predetermined only as an abstract event, not in its specifics.

The most important of the so-called Homeric terms of fate, $\mu$ oĩ $\alpha$, is crucial since its semantic field provides basic information about the actual underlying conceptions. The term $\mu$ oĩ $\alpha$ preserves its basic meaning "part/share", even though its range of application has broadened to include the "appropriate way" in which something is distributed and how man should speak and act. Moĩ $\alpha$ thus also expresses "the appropriate participation" of every individual in life events. The individual's position in the world and in society defines what is "appropriate", which should also be understood in the context of the cosmic and normative order. In this extended function, $\mu$ oĩ $\alpha$ also refers to the share allotted by the gods.

The term $\mu$ ó $\$ with its basic meaning of "share" similarly expresses the "appropriate or divinely authorized participation in life events". In some passages $\mu$ ó $\varrho \varsigma$ is more emphatic than $\mu$ oĩ $\alpha$, conveying the notion of "an individual's participation in the events and duration of life, accorded either by tradition or by the gods". The term $\alpha \tilde{i} \sigma \alpha$ likewise means "part" or "share". ${ }^{15}$ Like $\mu$ oĩ $\alpha$ and $\mu$ ó@os, $\alpha$ Ĩ $\sigma \alpha$ conveys both the notion of "(appropriate or apposite) share in life" and of "duly accorded participation in life events (usually by Zeus)". As general terms for participation in the events of life, all three terms thus occur as alternative

11 For a full treatment of all occurrences of these terms and phrases see SARISCHOULIs 2008a, 27-128 (= Chap. II.1: "Zur Schicksalsvorstellung Homers und zu den zugehörigen Ausdrücken”).

12 All translations of the Homeric text in this paper are my own.

13 On the etymological derivation of $\mu$ oĩ $\alpha$ and $\mu$ ógos cf.: Lejeune 1972, 119 a. 155; PALmer 1980, 225 a. 236; LfgrE, s.v. $\mu$ oĩ $\alpha$.

14 Aphrodite saves Alexandros (Il. 3.380-382), Hephaistos Idaios (Il. 5.22-24), Poseidon Aineias (Il. 20.321325), Apollo Hector (Il. 20.443-446) and Agenor (Il. 21.596-598).

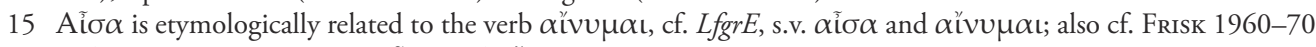
and Chantraine 1968, s.v. $\alpha$ ĩo $\alpha$ and $\alpha$ ǐvv $\mu \alpha$ i; Bianchi 1953, 2; Lejeune 1972, 103; Peters 1980, 75.112. 140 n. 94. 
formulas for death, especially in the context of war, ${ }^{16}$ since this is the final and universally shared aspect of life. ${ }^{17}$ The meaning of the term kń varies between "death as allotment" and "form of death". ${ }^{18}$ The term $\pi$ ó $\mu$ os usually carries the meaning of "death as allotment"19 and is used as a synonym for death. In some passages, however, $\pi$ ó $\tau \mu \circ \varsigma^{20}$ seems to mean "the measure of days one is allotted in life". Even more palpable is the meaning of the term oĩtos: $:^{21}$ "the path of life that leads to death". In this meaning, oĩtos signifies "the path through life", "life including its end", but also "the end of life" and thus functions, like the other terms, as an alternative description for the final share in life, namely death.

\section{Fundamental Beliefs: Views of the world, views of life, and the inevitability of death}

$\mathrm{O}$ ne must note, therefore, that these terms of fate transport neither the inevitable predetermination of life events by a preordaining force, nor a concrete belief in fate. ${ }^{22}$ Instead, these semantic fields show how Homer himself (and thus the people depicted in his epics and most likely also a large part of his contemporary audience) understood the world. Not "fate", ${ }^{23}$ but the capacity for perception actually portrayed in the Homeric epics and the resulting world view must therefore take centre stage in the analysis. The so-called terms of fate are read here as containing traces of social attitudes and expectations, ${ }^{24}$ as well as a certain understanding of life: life is seen as a sequence of interconnected "shares" that can be understood in sum as a divine allotment. The result is a path, the path of life that consists of shares in the events of life. These shares can be related to the cosmic and/or social and moral order; people are thus accorded their shares either due to their status as living beings or due to their position in society.

As far as this path through life is concerned, there are no predetermined allocations of shares in the events of life; there are thus no preordained events. The path through life has no predetermined course, but rather exists as a compound of alternatives, actual and not simply offered pro forma. Only one single event is predetermined, and accordingly known, since the end of the path through life is clear for all mortals. Death as the final share in life inevitably

16 Leitzke 1930, 32, for example, also describes the term $\alpha$ ĩo $\alpha$ with regard to $I l .16 .441$ as an "Deckname für "Tod"' ["alias for death"].

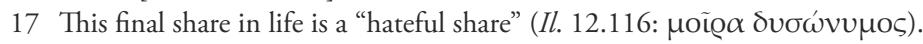

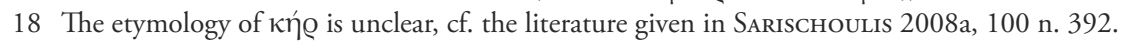

19 The usual interpretation of $\pi$ ó $\tau \mu \circ \varsigma$ as "death as allotment" must also be assumed for its adjectival derivation

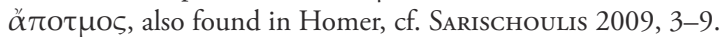

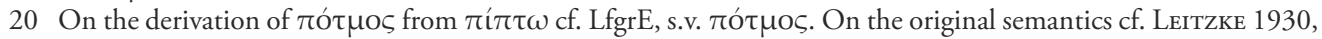
36; Krause 1936, 144; Luther 1954, 58; Dietrich 1965, 12; Chantraine 1968, s.v. $\pi i ́ \pi \tau \omega$.

21 The etymology of the term oĩtos is uncertain, cf. the discussion in SARISCHOULIS 2008a, 122 with n. 505-511 (with literature).

22 Cf. Nilsson 1967-1974, I 361-368, who not only rejects the claim that a "persönliche, konkrete Göttin" ["personal, concrete goddess"] underlies the so-called terms of fate, but also opposes every possible conception that would relate the semantics of terms such as $\mu$ oĩo $\alpha$ and $\alpha \tilde{I} \sigma \alpha$ to the later philosophical conception of fate embodied in eí $\alpha \propto \mu \varepsilon \dot{v} \eta$, which expresses "das Schicksalsmäßige im Sinne der unvermeidlichen Notwendigkeit".

23 Cf. SCHein 1984, 63: "When we translate moira, moros, or aisa as 'fate', we must avoid importing with the translation a concept of destiny that is in no way Homeric."

24 This nuance of meaning is particularly noticeable in the usage contexts of the prepositional phrase $\kappa \alpha \tau \dot{\alpha}$ $\mu$ oĩo $\alpha v$; for a discussion of its occurrences cf. SARISCHOULIS 2008a, 43-44. 
awaits all living things. Being allotted a share in life automatically and without exception includes a share in death. This fundamental principle of the cosmic order grants no living being an alternative: all who are born are subject to the basic precondition of life, i.e. inescapable death. This realisation is a fundamental aspect of the world view visible in the Homeric epics. The so-called terms of fate clearly express this unavoidable necessity. ${ }^{25}$ If there is anything in Homer's epics that is considered an absolute power, then it is neither the power of fate nor the power of the gods, but the power of death.

\section{Death as the basis for the development of a belief in fate}

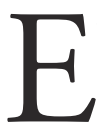
ven though death only accounts for the tiny final share in life, it nevertheless crucially shapes the world view due to its inevitability. In my view, the perception of death as an inescapable part of life forms the basis for the later notion that every single share in life is preordained by a force of destiny. The notion could conceivably have developed in these five stages:

1. Death is an event that is fixed and inevitable for all living things, and is hence predetermined.

2. If death is a predetermined event for all living things, then the exact time of death must also be preordained.

3. If the exact time of death is preordained for every living thing, then the other circumstances of death are likewise predetermined.

4. If the exact time and circumstances of death are predetermined, then they must be established at a specific point in time, which must then be the moment in which the first share in life is allotted, so the moment of birth. Hence, the length of an individual's life is set down at birth.

5. If the exact time and circumstances of death are predetermined, one must finally assume that not only the length, but also the contents of life, understood as a linear sequence of events that lead from birth to death, are likewise predetermined. Only in this final stage can one speak of a fully developed belief in destiny.

\section{Locating Homer's “conception of fate”}

I f one considers these five stages of development, one soon realises that the Homeric epics do not even consistently exhibit the idea that the exact time of death is predetermined; this means that not even the second rung of this ladder has been fully climbed. The existence of isolated passages that provide the basis for the third and fourth stage of this scheme does not mean that the Homeric epics express a general, dominant view according to which the duration of life or the time of death, including the precise circumstances and causes, are preordained and compel humans to inescapably adhere to these provisions. A belief in the omnipotence of

25 Cf. Schwabl 1954, 60, who points out the fact "dass $\mu$ oĩ $\alpha$ kein abstrakter Begriff ist und ebenso die einzelne Gabe (etwa $\alpha i \delta o \tilde{c} \varsigma$ roĩ $\alpha$ Od. XX, 171) wie auch das dem Menschen nach seiner Natur Zukommende, also vor allem den Tod, bezeichnen kann. Im Denken um den Tod kreist denn auch vor allem die Idee der Vorbestimmung." 
a force of destiny that shapes the life of every human being out of preordained events cannot be identified in the ways of thinking and acting portrayed in the Homeric epics.

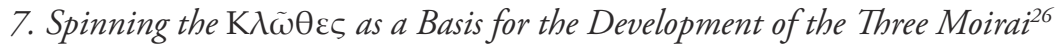

$\mathrm{H}$ omer shows the following development: the original thought seems to have been the conception of life as a path, a journey with a beginning and an end. The vulnerability and fragility of life that is already sealed with a predetermined final event was very probably evident to people already before Homer. ${ }^{27}$ As a result, one seems already in Homer's time to have begun to compare one's journey through life to a thread that begins at birth and is inevitably torn at the end. Reference points for moira, meaning the share in life and concomitant share in death, are beginning and end, birth and death. This comparison - rather than a generally established concept - is visible in two passages of the epics that treat life as a thread, ${ }^{28}$ which the "spinners" (Od. 7.197: K $\left.\lambda \tilde{\omega} \theta \varepsilon \varsigma\right)$ have finished spinning already at birth; in this case, the exact circumstances of death seem to have been established already at birth. But in Homer's epics, the allotment of prosperity and ruin, of safe return and suffering etc. is not the responsibility of an independent force named Moira (or Moirai), but the charge of the gods; in such scenarios we often find the word $\delta \alpha i \mu \omega v$.

Only in post-Homeric times does this metaphor take more elaborated form and Moira comes to be subdivided into three: comparing the journey of life to a thread caused the personified allotment of the final share in life to take the shape of a spinner. The notion of a spinner tearing off the thread, and thereby ending life, led in due course to the addition of another spinner responsible for getting the thread started, i.e. for the beginning of life. Having a spinner for both death and birth leads to the notion of a third spinner who keeps up the spinning until the thread is severed. Her charge is thus the thread itself, i.e. life.

\section{The Basic Scheme: "Action - consequencelreaction"}

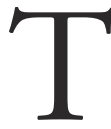
hese thought processes and ideas do not, however, make themselves felt in the world of Homer. The fundamental scheme that underpins the sequence of events in both epics consists of a basic formula of "action - consequence/reaction". This is a compact narrative scheme that depicts the events of Iliad and Odyssey not as a sequence of independent individual events but as a chain of closely linked components that come together to make a whole. Within this basic scheme, an event is considered and described as the basis for the genesis of another, and so forth. This scheme does not, however, result from a conviction that every event is predetermined, but is in fact dependent on the two following assumptions:

26 On the function of the Moirai in literature and cult in ancient Greece see the detailed report in PirenNeDelforge \& Pironti 2011 (with literature).

27 Отто 1947, 260, postulates a primal belief that included the notion of "einer Bestimmung, die den Untergang und Tod festsetzt"; cf. also ErbSE 1986, 284, who refers to "eine uralte Erfahrung des Menschengeschlechtes" in this context: "Der Tod wurde von jeher als die unüberwindbare, aber auch als die unverständliche Grenze des menschlichen Daseins erlebt."

28 Once each in Iliad and Odyssey: Il. 20.127-128 and Od. 7.196-198. 
1. Every action that breaches the limits of the cosmic and social order results in a reaction.

2. There are concrete reasons for everything that occurs in the world.

This narrative formula has consequences. The development of the action itself - both in general and in each particular instance - remains free and independent of predetermining factors in both epics. Instead, a number of contributing factors come together to determine how the action unravels. These contributing factors are nothing less than the plans and actions undertaken by the human and divine figures, whom Homer deliberately depicts in their capacity as actors. The story of the two epics is fundamentally based on free decisions and the resulting deeds undertaken by the characters, humans and gods alike, who are themselves in control of the motivations that trigger their actions. In this respect, men and gods are treated alike in Homer: every single god and every single human is deliberately and consciously assigned the status of an agent. In the Homeric narrative mode, every character acts the way it does because it has concrete idiosyncratic concerns of its own choice. Any and all action thus depends on the individual actor.

This reflects a basic principle of the Homeric narrative mode, namely that the focal point of the narrative consists in the explicit - or opaque - motivations of the respective actor. Story development in Iliad and Odyssey is thus based on a dense mesh of personal desires and aims harboured by human and divine actors. These desires and aims are the causes of the actions performed, which in turn elicit reactions and have consequences.

This basic scheme of "action - consequence/reaction" can easily be confirmed by taking a look at the causes that motivate the genesis and further development of the action in the Iliad and the Odyssey. Such an approach smoothly highlights the pivotal role Homer grants the "human factor".

Already the first four verses of the Iliad identify not a god, ${ }^{29}$ not $\mu$ oĩo $\alpha$, but a human (Achilles) and his wrath as the cause of the mounting Achaian death toll. This wrath is triggered by another human's ü $\beta \mathrm{Q} \varsigma^{30}$ (Agamemnon), whose misconduct is triggered by the wrath of a god, Apollo (Il. 1.9). The wrath of the god, the result of a prayer by one of his priests, was itself caused by Agamemnon's first act of üß@ıৎ, which consists of ignoring the priest. ${ }^{31}$ This first act of wrongdoing by the Greek leader is itself a response to the act of another human, namely the plea of the priest Chryses, who asks for the return of his daughter.

Chronologically, the events play out in the following way: Chryses enters the Achaian camp and requests the release of his daughter. The reaction to his plea leaves much to be desired: while all the other Achaians acquiesce (Il. 1.22), Agamemnon refuses (24) and chases the priest away with threats (25). Agamemnon's breach of conduct causes the priest's prayer to Apollo, which in turn results in Apollo's reaction and its famously devastating consequences for the entire Achaian army. One must note with emphasis that Apollo acts here not as a warden of order, but as a powerful protector of "his" man. ${ }^{32}$

29 Even though Homer himself asks some lines later (in verse 8), which god caused the dispute among the Greeks, his portrayal of the causes for the dispute does not actually show any divine involvement. As FräNKEL 1962, 71 n. 1, remarks, "die Kette der Ursachen und Wirkungen beginnt schon vor Apollons Eingreifen".

30 On the use of $\ddot{\beta} \mathrm{Q} \varsigma$ and its contexts cf. SARISCHOULIS 2014.

31 Cf. Lesky 1961, 16-17, who notes "dass wir als letztes Aition nicht einen über allem stehenden Plan des Zeus, sondern die unbedachte Tat eines Menschen erfahren, der sie nicht unter göttlichem Einflusse, weit eher als Widersacher eines Gottes tut".

32 Cf. Wilamowitz-Moellendorff 1956, I 357: "Wenn Apollon die Pest sendet, weil Agamemnon dem Chryses seine Tochter nicht zurückgibt, erzwingt das der Gott als Beschützer seines Priesters, nicht um die Ungerechtigkeit zu bestrafen". 
Agamemnon's reaction to the divine act results in his second breach of conduct: although the Greek leader returns the priest's daughter, he underestimates the pivotal importance of Achilles for the war effort against Troy and demands Achilles' gift of honour, Briseis, as a replacement for Chryseis. Agamemnon comes out on top and thereby causes Achilles' fierce reaction, his wrath.

We can therefore note that the personally selected motivations and resultant actions of three human beings, Chryses, Agamemnon, and Achilles, provide the actual causes for the action of the Iliad.

This scheme of "action - consequence/reaction" continues to apply throughout the story of the Iliad. Achilles' wrath leads him to withdraw from fighting, but also to entreat Thetis to speak to Zeus on his behalf and ensure compensation. The notorious $\Delta$ iòs $\beta$ ov $\lambda \eta$, the much discussed plan of Zeus, is solely intended to aid the Trojans on the field of battle ${ }^{33}$ and is caused by a human (Achilles) - a fact that deserves extra emphasis. The Trojan superiority in battle, however, causes the Achaians to suffer great losses. Furthermore, the grumbling hero had evidently not considered that his friend Patroklos might be among the fallen. ${ }^{34}$ When this happens, Achil-

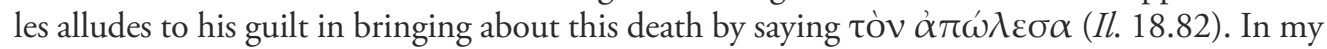
view, this phrase does not mean "him I have lost", but rather "him I have destroyed".

Is Patroklos' death really a consequence, triggered by Thetis' plea to Zeus? I would say "yes". Thetis' plea was a transgression, described elsewhere as "inappropriate" or "contrary

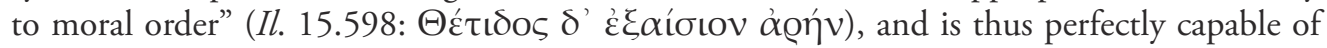
triggering a reaction. Simultaneously, the plea is an instance of wrongdoing, since it is the starting point for Achilles' irresponsible attitude and imprudence - his action is obvious an act of (high) treason! Achilles thereby triggers events with devastating consequences, both for the Achaian camp as a whole, and for his own person.

The plea to Zeus does not itself cause the death of Patroklos; the true culprit is another instance of misconduct by Achilles: The hero is stubborn in his wrath and remains unmoved even by the Achaian envoys and their tempting offer in book 9, as well as the mounting number of Achaian casualties and the weakening Greek defence. The reaction to Achilles' implacable attitude is the decision made by his friend Patroklos to fight the Trojans on his own. During this battle Patroklos tries to defeat Troy by himself and obviously the hybris of this act ultimately causes his death. Patroklos' death in turn triggers Achilles' final decision ${ }^{35}$ in the $18^{\text {th }}$ book of the Iliad (98-126) to rejoin the fray in order to avenge his friend by defeating Hector. He thereby decides to accept the risk of his own quick death.

The applicability of the "action - consequence/reaction" scheme can also be traced in the Odyssey. The beginning of the first book of this epic (verses 7-9) confronts the reader with the observation that the comrades of Odysseus are themselves responsible for their peril "due to their

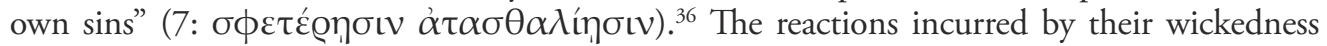

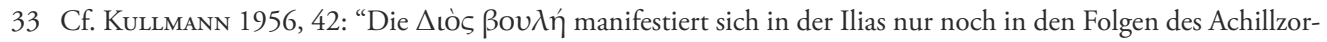
nes und dem damit in Zusammenhang stehenden Thetisversprechen".

34 Cf. Schadewald 1966, 112: "Bald wird ja der Ausgang der Patroklie zeigen, wie das Verlangen des Achilleus, die Achaier zu strafen, sich gegen ihn selber kehrt".

35 Dietrich 1965, 188, considers Achilles the only person "of whom it can truly be said that he had been given a choice; but Achilles only once mentions this choice open to him", in precisely this passage.

36 Cf. Od. 12.300: $\alpha \tau \alpha \sigma \theta \alpha \lambda i ́ n \sigma \iota v \kappa \alpha \kappa \tilde{\eta} \sigma \iota v$, the "evil transgressions", likewise applied to Odysseus' comrades after they have decided to agree to the "evil proposition" made by Eurylochos, namely to slaughter and consume the cattle of Helios. 
deny them their coveted return home and punish them with death in its stead; Homer does not hesitate to call them "fools" or "idiots" (8: vท́tııı).

The applicability of the belief that an "inappropriate" action triggers a reaction with extremely unpleasant consequences can be traced also in other passages. Odysseus, for example, warns the suitor Amphinomos not to be negligent, careless, reckless or overreaching, whereas in the $18^{\text {th }}$ book, he claims to have acted this way himself when he was younger (139: $\pi \mathrm{O} \lambda \lambda \dot{\alpha}$

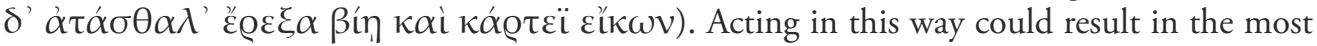
terrible consequences; hence it is vastly preferable to accept the gifts of the gods without ques-

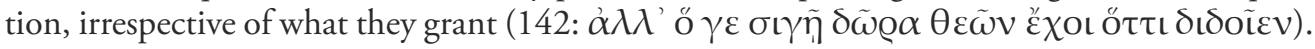

In uttering these words, Odysseus is making a futile attempt to alert the suitor, whom he finds somewhat agreeable, of the peril all the suitors are about to face. With a strong belief in self-determination, Odysseus advises Amphinomos to adhere to the laws of the world order, since this is the only way to achieve self-sovereignty. If he, however, insists on inappropriate behaviour, this will incur a reaction that entails peril and destruction. Amphinomos ignores Odysseus' advice and dies alongside the other murdered suitors, pierced by Telemachos' spear (cf. Od. 18.156 and 22.91).

Odysseus also appeals to this scheme of "action - consequence/reaction", when he explains the rationale behind the murder of the suitors to Eurykleia in the $22^{\text {nd }}$ book of the Odyssey. In verse 413 he speaks not only of their "shameful deeds" ( $\sigma \chi \varepsilon \dot{\varepsilon} \lambda \iota \alpha$ č $\gamma \alpha)$, but also

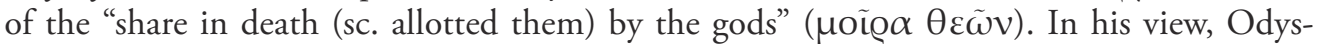
seus serves the restitution of moral order by killing the sinful suitors. ${ }^{37}$ The next two lines (414-415) explain how exactly the suitors breached the rules of this order: They disrespected all living men, even those worthy of respect. For this reason, their "wicked deeds" (416: $\dot{\alpha} \tau \alpha \sigma \theta \alpha \lambda i ́ n \sigma \iota v)$ have caused them to draw "the shameful allotment of death" ( $\dot{\alpha} \varepsilon$ เ $\varepsilon \dot{\varepsilon} \alpha$ $\pi$ ó $\tau \mu \mathrm{ov})$. Viewed like this, the $\mu$ oi̊ $\alpha \theta \varepsilon \tilde{\omega} v$ should be understood as a causal reaction to the suitors' breach of moral order.

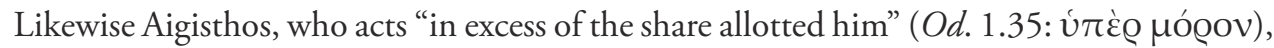
also has to expect consequences for his actions. In Zeus' narrative, he takes Klytaimnestra home as his bride in defiance of Hermes' warning. Aigisthos' motivation lies solely within himself, and simultaneously agrees according to Homer's narrative with Klytaimnestra's similarly idiosyncratic motives $(O d$. 3.272: $\dot{\varepsilon} \theta \dot{\varepsilon} \lambda \omega \mathrm{v} \dot{\varepsilon} \theta \dot{\varepsilon} \lambda \sigma v \sigma \alpha \mathrm{v})$. As a consequence, he cannot

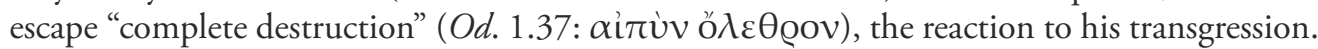

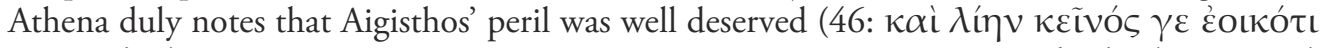

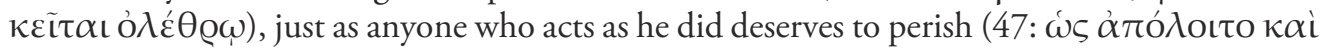

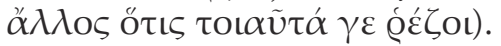

One must emphasize that, according to Zeus, the gods do not prohibit, command or prescribe anything to influence the human actor at this point. Instead, they make him aware of the boundaries set by the cosmic and moral order. This course of action constitutes a warning, confirming the validity of the scheme "action - consequence/reaction": Any transgression of the cosmic and moral order will result in a reaction that will have extremely unpleasant consequences for the culprit or sinner.

37 Cf. Eberhard 1923, 67: "Die Götter haben den Freiern wegen ihres schändlichen Treibens das ihnen Gebührende (hier den Tod) zugeteilt". Eberhard thus interprets $\mu$ oĩ $\alpha$ not as "fate", but as "allotment". Thus $\mu$ oi $\alpha$ should here be understood as a label for "what the gods send as punishment for wrongdoing". 
The applicability of this scheme of "action - consequence/reaction" is not limited to cases in which the reaction to wrongdoing is the ultimate punishment; i.e. the reaction triggered need not necessarily result in death. When Odysseus' comrades voluntarily make the wrong decision in the $10^{\text {th }}$ book of the Odyssey and accept Kirke's invitation, they must consider the possibility that this will lead to them partaking of less than desirable life events. Eurylochos, who refuses the invitation, continues to be his own master. Insight and providence are the best foundation for the identification of "appropriate" action, which avoids reactions with unpleasant consequences.

Although triggered reactions to breaches of (world-)order are the basis of the scheme "action - consequence/reaction", there are also cases in which a reaction is not the result of wrongdoing, but of "proper" or "appropriate" behaviour. As one can see in the various predictions made, e.g., by Teiresias or Proteus, ${ }^{38}$ the human actor is capable of consciously selecting an "appropriate" action that results in a "desired" reaction.

An analysis of the causes that underlie the narrative development of the Odyssey similarly reinforces the validity of the scheme "action - consequence/reaction", but mainly in the "positive" sense identified in the previous paragraph. The foundation on which the action develops is the unwavering and omnipresent decision of Odysseus to return home. ${ }^{39}$ The hero made this decision without any outside involvement; it stems from inside him. The Odyssey contains no evidence that a deity or force of destiny had any influence on this decision.

Furthermore, Odysseus made this decision before the epic even began, long before he even arrived on the island of Ogygia. In his own account, offered in the apologoi on the island of Scheria, he states that his decision was already firmly established when he left Troy after the conquest. This is unambiguously confirmed by Homer's description of the pain, which the ongoing failure to return home causes his hero $(\mathrm{Od}$. 5.151-58), as well as by Athena's explanations (Od. 1.48-62 and 5.13-17).

Already at the very beginning of the Odyssey, Athena speaks of the hero, who is currently

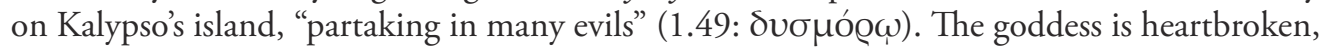

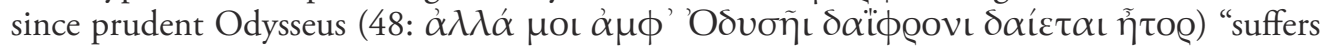
misery" far from his loved ones (49: $\pi \eta \dot{\mu} \alpha \tau \alpha \pi \dot{\alpha} \sigma \chi \varepsilon \mathrm{\iota})$. Odysseus' decision and its foundation, the heartfelt desire to return home, thus existed before the story of Odyssey began, as did the suffering born of this long-standing yearning.

This suffering is what causes the reaction that proves to be Odysseus' boon: Athena comes to the conclusion that Odysseus' suffering is unjustified (59-62), which is why it touches her heart. Unknowingly, Odysseus thus triggers a "positive" reaction from Athena by means of his suffering. The hero induces the goddess to decide that his motives are worth supporting. Once Athena has made this decision, she acts accordingly and speaks to Zeus, aiming to make the ruler of the gods also accept the human's motives.

The validity of the scheme "action - consequence/reaction" is further confirmed by Zeus' response: Odysseus' suffering is not in fact unjustified, since he blinded Polyphemos, giving Poseidon grounds for revenge (64-70). As a consequence, the suffering of Odysseus is the reaction triggered by the hero's "inappropriate" behaviour. ${ }^{40}$ Despite this, Zeus is prepared to assist the hero in his quest.

38 See the next section for more details.

39 Cf. the argument in SARISCHOULIs 2008a, 263-267.

40 Cf. the discussion in SARISChOulis 2014, 71-72. 
As in the Iliad, the Odyssey thus confirms the observation that the causes for the development of the epic's story lie in human action and thus in the idiosyncratic and personally determined motives that are its foundation.

The sequences of actions and reactions (or consequences) we have traced in the narratives of Iliad and Odyssey show that interventions by supernatural forces (gods or fate) neither cause human reactions nor in fact determine the sequence of events in the Homeric epics. Instead, the individual human actor is the central focus of the narrative, since he bears the responsibility for his thought processes and aims, for the decisions and actions they entail, and (especially) for the resulting positive and negative consequences. "Appropriate" actions can generally be relied upon to have orderly consequences, or even the result specifically desired. If the (world-) order is violated, the consequences appear as reactions with devastating or at least very unpleasant consequences. ${ }^{41}$ The human actor, who is aware of this responsibility, therefore determines the development of the story both in general and in its specifics.

One must also note that the belief that every breach of the existing cosmic, moral, and social order results in a remarkably negative reaction is universally valid. In his reconciliation speech (Il. 19.78-144), ${ }^{42}$ Agamemnon refers to this generally valid conviction when he describes the delusion that led to his second show of misconduct, namely taking Achilles' gift of honour, as a reaction to his first act of wrongdoing, namely ostentatiously disregarding and insulting the priest Chryses.

Finally, the function of the Erinyes ${ }^{43}$ is also based on this conviction: in the Iliad, they rob Achilles' horse of its ability to speak (19.418), originally granted by Hera; in the Odyssey, the Erinyes force the daughters of Pandareos, delivered to them by the harpies, to labour as their slaves, after the goddesses Aphrodite, Hera, Artemis, and Athena were overly lavish in granting them blessings (20.68-72).

It is thus worth pointing out that the notion of a reaction to breaches of (world)-order in the form of negative consequences is not rooted in any existing belief in fate. The resulting reaction or consequence is to be considered neither a predetermined event, nor the result of an intervention by a super-ordinate force of destiny. This notion that any transgression of (world)-order has consequences is based on the primal belief in a balance inherent in nature and human society. The so-called terms of fate in Homer are not only a cipher for every-day use that refers to this fundamental principle of balance, but also encompass the demand that this balance is to be preserved, that people should be reticent and honour the boundaries that maintain balance in the world, in life, and in human society. This demand for balance entails concrete rules for an "orderly" every-day life; it deters from excesses; it encompasses a notion of universal regularity, which is not, however, an independent force, but an inevitable reaction to all human actions that breach the established border. ${ }^{44}$

41 Cf. Lesky 1961, 43: "In dieser Welt zählt eben die Tat als solche, das Faktische, das in der Ordnung der Welt als Un-Ordnung sichtbar Gewordene”.

42 Cf. the in-depth analysis of Agamemnon's appeasing speech in SARISCHOULIS 2008a, 46-54.

43 On the function of the Erinyes in Homer see SARISCHOUlis 2008a, 53-54 with n. 149-154 (with literature).

44 Cf. Schwabl 1954, 60. In his view, Moĩ@ $\alpha$ designates "das bestimmte menschliche Geschick, das zu überschreiten $\tilde{\beta}$ Qıৎ bedeutet und die Wiederherstellung der Ordnung fordert. Es heißt das für sich nehmen wollen, was die Götter nicht gewähren oder was schon einem anderen zugeteilt ist”. 
The scheme "action - consequence/reaction" with all its different facets can also be traced in the way divination is portrayed.

The first instance is found already at the beginning of the Iliad. The prophecy of Kalchas (1.93-100) is intended to provide information about the wrath of Apollo, the plague, and the numerous deaths in the Achaian camp. It is quite interesting to take a closer look at why it is Kalchas who can provide this information and which abilities characterise this man. According to Homer, Kalchas is capable of giving the background to this calamity since he

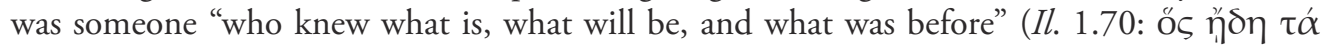

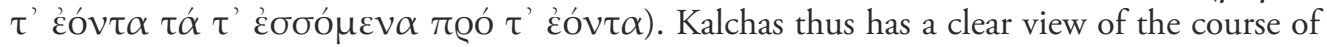
events. ${ }^{45} \mathrm{He}$ can evidently connect the dots and view events as a coherent sequence; this allows him to give information about the relations between individual events; hence he can distinguish between actions and causal reactions in any given sequence of events; as a result, he can identify a sequence of events as a chain of reactions to a specific action, and can thereby discern how the chain might be broken.

His divination takes the form of a short, compact, and insightful speech that discusses the causes of the calamity and the possible solution as a chain of actions and reactions/consequences, which in turn clearly identifies Agamemnon as personally responsible for everything that has occurred. Apollo is angry not because of missed sacrifices (Il. 1.93), but because of the priest Agamemnon disregarded (94). Since he did not agree to release Chryseis, the god has brought devastation down upon the Greeks and will continue to do so (95-96). The situation will only be resolved if the Achaians return the daughter to the priest without charge, accompanied by a devout hecatomb; by doing this the Achaians might be granted mercy $(97-100)$.

The god's reaction with its devastating consequences for the Achaian camp was thus triggered not by the "inappropriate" action suspected - the missed sacrifices - but by the improper actions of an individual, Agamemnon. The restitution of moral order, i.e. returning the daughter, in combination with the "correct" sacrifices constitutes the "appropriate" action that will result in the "desired" reaction, namely absolution from punishment. In this interpretation of past and potential future events, the human actor is considered responsible for all occurrences. $\mathrm{He}$ is also seen as self-determining and thus controls the development of the story.

This understanding of life is further confirmed by Achilles' report of his mother's (pre)diction (Il. 9.410-16): twofold allotments of death are bearing him towards the doom of death

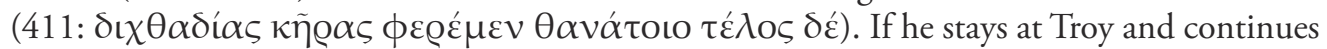
fighting, he will not return home, but acquire eternal glory (412-413). If he returns to his homeland, he will have long to live before he dies, but has to forgo glory (414-416). Achilles is aware that his death is predetermined, like for every other living being. "For not even the

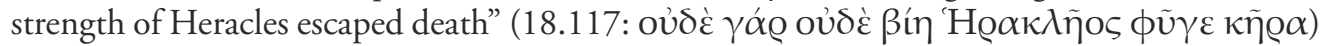
- but he can decide where, under which circumstances, and with which long-term effects this event shall come to pass.

45 Cf. SNELL 1975, 142-143: "Kalchas durchschaut also das Vergangene, das Gegenwärtige und das Zukünftige in ihrem Zusammenhang, [...] der sich in Aktionen und Gegenaktionen von der Vergangenheit bis in die Zukunft erstreckt". 
Achilles thus understands his loving mother's statement not as a fatalistic prediction, but as a piece of caring advice that even highlights Achilles' pivotal role in shaping his own future. Achilles is faced with a choice; ${ }^{46}$ his own decision ${ }^{47}$ will trigger either one or the other reaction, cause either one or the other prospective outlook on life to be realised as a consequence of the actions that result from his decision. ${ }^{48}$

As long as the hero does not act, his life will not change; the flow of events will continue to pass him by, he will simply be overtaken by the events, as is the case from the beginning of his wrath until the death of Patroklos: he will experience neither glory, nor combat, neither peaceful life at home, nor death. If he acts in one of the two ways just outlined, however, he unlocks the corresponding future. Acting in a third, unlisted way - a possibility that is never excluded in the Iliad at any point - might open up further opportunities. Everything is possible, if one prerequisite is fulfilled: in order to mould his future life, Achilles has to make a decision and act accordingly.

Like Thetis, the seer Polyidos has also frequently pointed out to his son Euchenor that he is

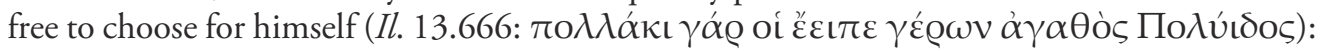

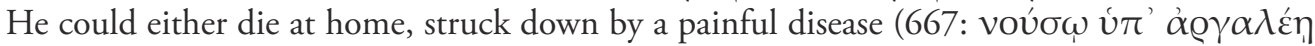

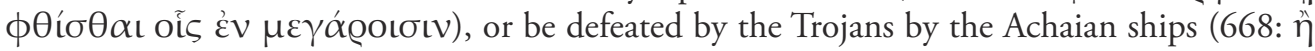

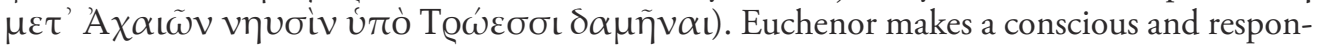
sible decision in favour of battle, even though he is aware of the consequences of his decision: "He embarked upon his ship knowing full well about the deadly allotment" (665: ö @ @’ ع̌v

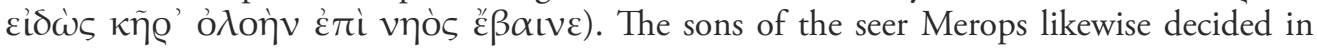
favour of war and thus caused their own deaths $($ Il. 2.831-34 = 11.329-32), despite their

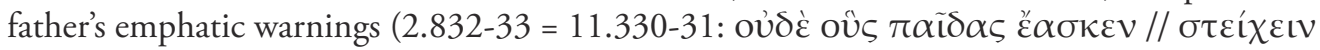
غ̇ऽ то́ $\lambda \varepsilon \mu$ ov $\phi \theta$ เớvo@ $\alpha)$.

The prediction Proteus makes concerning the return of Menelaos (Od.4.475-80) also treats the desired future development of the story as the result of the personal accomplishments of the hero in question. That means that the "appropriate" action, i.e. making the "correct sacrifi-

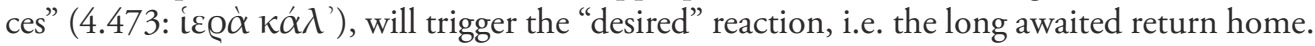
Also in this case, nothing is predetermined; a resolute actor is required to bring about reactions: Menelaos will not return home (475) before he has not sacrificed hecatombs to the gods

46 Cf. WolfF 1929, 391, who rightly notes: "Was hätte denn überhaupt das Aufstellen dieser Alternative für einen Sinn, wenn nicht eine Wahl daran geknüpft ist? Sollte Achill keine Wahl haben, dann hätte die Weissagung nicht anders lauten können als: er werde vor Troja bleiben, sich unvergänglichen Ruhm erwerben, aber einen frühen Tod finden." "'What would the point be of having an alternative if there is no choice connected to it? If Achilles did not have a choice, the prediction would be final: he will stay at Troy, earn undying glory, and die an early death."].

47 Differently SNell 1975, 105: "Da ist es Achill nur als Schicksal gegeben, entweder ruhmvoll jung zu sterben oder lange, aber unbekannt zu leben”; similarly SchadEwALdT 1965, 254: "Das Kommende, das ihn (sc. Achill) erwartet, ist eben nicht erst Folge eines eigenen Entschlusses, sondern ist gegebene Schicksalswirklichkeit, ihn nicht minder bestimmend als das Vergangene, das ihn bedingt."; cf. also Adkins 1970, 24: "Here there is no question of a decision, for of two possibilities the one is not even considered“; but Morrison 1997, 280, objects: "Yet the poet shows us that Achilles does make decisions. In fact most of the key events of the Iliad are determined by the choices of the heroes"; cf. IDEM 275: "It is possible to speak of Achilles making a decision because we find Zeus and the poet doing quite similar things."

48 A different view of the passage is expressed by SNELL 1928, 22: "Achill hat selber keine Wahl. Ihm bleibt nur, das Leben in seiner Begrenztheit hinzunehmen.” Erbse 1986, 233, agrees with Snell's view, since Achilles has "seinen persönlichen Heldenruhm im Auge". 
in Egypt (477-479). ${ }^{49}$ Only then will the gods grant him what he desires (480: $\delta \omega \sigma o v \sigma \iota v$

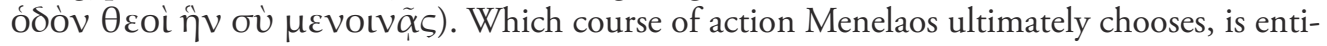
rely up to him.

The pivotal role of the actor's contribution in shaping his own future is most clearly expressed in Teiresias' cautioning divination $(O d .11 .100-118)^{50}$ concerning the possible return of Odysseus and his comrades. It is also clearly placed in the context of an "action - consequence/reaction" scheme. This can first be deduced from the structure of the divination: it consists of a sequence of conditional clauses that closely address the various conceivable options.

The content clearly points in the same direction: in Teiresias' statement, the outcome of the journey is not fixed; not even divine intervention can decisively influence it, since Poseidon can evidently hamper their progress (cf. verses 100-103), but not entirely prevent their journey home: "Yet even so they will reach home" (104: $\alpha \lambda \lambda$ ' $\pi \alpha \dot{\alpha} \sigma \chi 0 v \tau \varepsilon \varsigma$, í $i(\sigma \theta \varepsilon)$. What does the success of their efforts depend on then, if it is not the power of fate and divine intervention?

The answer to this question is provided by the occurrence of the verb $(\dot{\varepsilon}) \theta \varepsilon \dot{\varepsilon} \lambda \omega$ "I am wil-

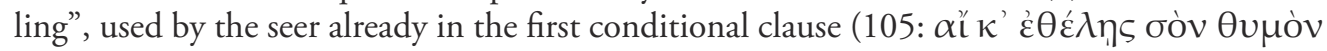

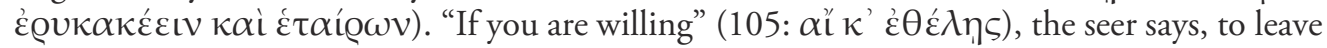
the cattle and sheep of Helios unharmed, they will return home safely! The "appropriate" action, i.e. leaving the cattle of Helios in peace, will - as in the case of Menelaos, who, unlike the comrades of Odysseus, complies with the advice he is given and therefore returns home - result in the "desired" reaction, the safe journey home. As the following conditional clause shows, the "desired" reaction will apply not merely to Odysseus alone, but to everyone (!) (111:

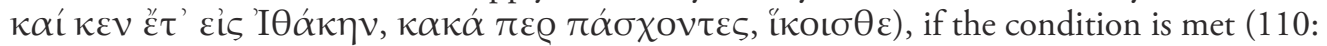

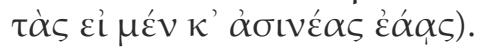

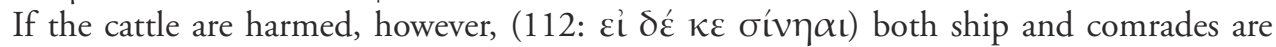

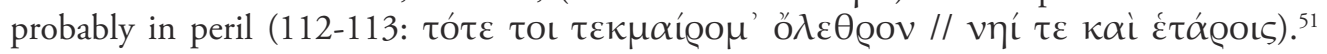
This conditional clause thus outlines the devastating consequences of the reaction triggered by an "inappropriate" or "unlawful" course of action. And even if Odysseus himself should

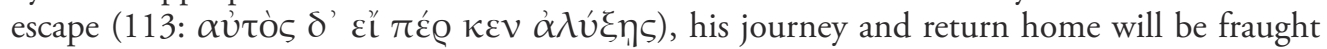
with suffering.

The final conditional clause unambiguously states that the final outcome of the triggered reaction and the extent of its devastating effects remain undetermined at present. These events are evidently not predetermined. Instead, Teiresias singles out Odysseus, emphasizing his resilience and agency: With Odysseus as an example, this final clause thus highlights the pivotal role of the human actor in shaping his future. His determination and sense of purpose are capable of overcoming even the most devastating consequences of any given reaction.

The content of this prediction clearly proves that there is no belief in fate in the Homeric epics, which would cause the future to be portrayed as consisting of fixed, inevitable events,

49 Thus Отто 1947, 265 notes: "Menelaos, der dies von sich selbst erzählt, hat hören müssen, dass es ihm nicht vergönnt ( $\mu$ oĩ $\alpha$ ) sei, die Heimat wiederzusehen, ehe er nicht wiederum die beschwerliche Fahrt nach Aegypten zurückgelegt und dort den Göttern geopfert habe."

50 The prediction made by Teireisias can be compared to Kirke's warning (Od. 12.127-141), who likewise advises Odysseus to spare the cattle of Helios with regard to his desire to return home.

$51 \quad 11.112-114=12.139-141$ (Kirke). 
both in the short and the long term. Neither fate, nor the gods determine the future. Instead, the human actor is the sole determinant of his fate, since his efforts are called for on every occasion: his motives and his personal desires and aims, the decisions they produce and the actions that follow from them are absolutely crucial in shaping his future.

\section{Omens}

lthough people were therefore aware even then that their actions decisively contribute
to their futures, Homer also shows evidence of the belief that certain aspects of the
present, e.g. natural phenomena or similar figurations, contain information that can be used to predict the future or give concrete hints of future events. Halitherses, for example, knows about bird omens and can interpret them appropriately $(O d$. 2.159: ó@vı $\theta \alpha \varsigma \gamma v \tilde{\omega} v \alpha \iota$

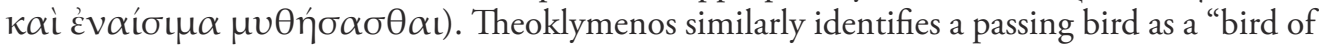

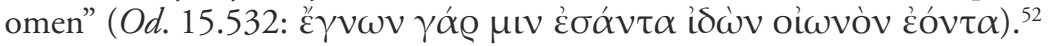

Like predictions, the interpretation of bird omens and similar procedures do not disclose a predetermined, inevitable future, but are indicators of possibilities or of various existing alternatives. Any given interpretation of an omen becomes binding only when it becomes linked to the deeds of a human actor. Human action alone directs the shape of the actor's future.

As a result, the validity of omens, which are based on random events in nature, and their interpretations are challenged in the Homeric epics. The suitor Eurymachos, for example, raises a pragmatic concern regarding Halitherses' interpretation of the bird omens: Many birds fly to and fro, but not all their paths are to be interpreted as omens ${ }^{53}(O d .2 .181-182$ : ö $\varrho v \vee \theta \varepsilon \varsigma$

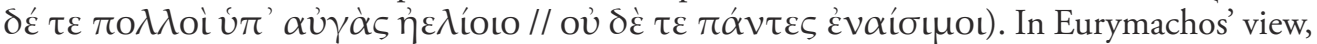
every flight of every bird could thus be considered an omen and interpreted at random; one should not, however, necessarily rely on this information.

Hector too evidently has a rather low opinion of omens. His attitude is clear: "I pay them (sc. the ominous birds) no heed, nor do I care whether they fly to the right, toward the dawn and the sun, or to the left toward the murky darkness" (Il. 12.238-240: $\tau \tilde{\omega} v$ oú $\tau \iota$

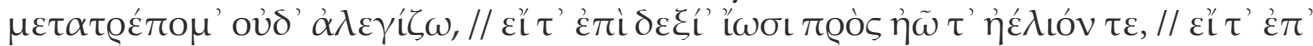

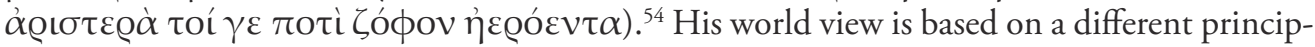

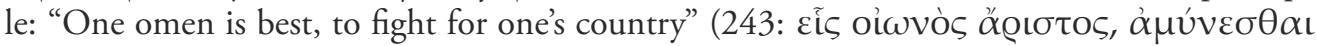

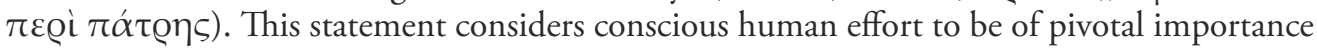
in shaping the future and nicely encapsulates Hector's attitude towards life: what really counts for the hero is independent action. Acting "appropriately" increases the probability that one will be able to shape one's future according to one's own ideas and desires. Ultimately, one can rely only on one's own powers; focused on a "correct" motive, they provide the best way of attaining one's goals.

52 Cf. STOCKINGER I959, 110.

53 Leitzke 1930, 33, rewrites the passage as follows: "Viele Vögel fliegen unter dem Himmel, nicht alle sind schicksalhaft"; according to Burkert I998, 193, this means "dass nicht jeder Vogel Träger eines Zeichens ist".

54 But Stockinger 1959, 164, claims that neither Homer nor his heroes would dare "die objektive Geltung der Vorzeichen anzuzweifeln". 


\section{Gods}

A

$s$ has already been noted, the world portrayed in the Homeric epics is viewed as an orderly system, governed by a cosmic and moral order. In this world, the gods appear as part of this ordered system, without functioning as an absolute, all-powerful sovereign that determines everything. ${ }^{55}$ In the Homeric epics there is no space for the effects of such a power, since the poet portrays his human and divine figures as possessing freedom of decision and action. In a world populated by self-determining humans, who select their own motivations, make their own decisions and act in full awareness of their independence, it is impossible to let all-powerful gods play their part. ${ }^{56}$

Therefore, every god is but a sub-power of the world that takes effect and acts independently. The similarity of the gods to humans is emphasized on every occasion; ${ }^{57}$ one might even say that Homer imagines the gods in a largely human way $;{ }^{58}$ they show positive and negative characteristics $^{59}$ and act in both expected and unexpected ways. Just like the humans, the gods in the Homeric epics are to be understood as independently acting characters with motives that underscore their actions. These anthropomorphic gods should finally be considered supernatural forces that are involved in the events of the world and participate in the development of the story, but do not predetermine anything.

The function of the gods is then, on the one hand, to allot the shares in life events, and on the other to preserve the order of the world. In choosing how to act they thus often take into account the norms of the cosmic order. While they are thus always aware of how they should act, they do not always behave accordingly; like humans, Homer understands and presents them as acting characters that are solely responsible for their motives and the resultant actions.

In this sense, every god determines his own actions according to his own notions, aims and desires. Since they are not omnipotent, however, it is possible for gods to fail in their endeavours. This can happen as a result of overconfidence or due to the superiority of another god, who is himself intent on fulfilling his own aims and desires. Every god thus experiences the limits he is inevitably set. ${ }^{60}$

55 Cf. Kraus 1984, 22, who notes that the gods are "mächtig, wenn auch keineswegs allmächtig".

56 Cf. Lloyd-Jones 1983, 10: "If we strike a proper balance, we must acknowledge that Homer's gods are effective and his religion real, but that his human characters are free to decide and are responsible for their decisions."

57 In addition to their human form, the gods possess "alles verklärt und vollkommen, was bei uns unvollkommen und flüchtig ist", observes Отто 1947, 158; according to Kraus 1984, 20, the gods are an "ideale Spiegelung menschlichen Daseins"; cf. finally ScHein 1984, 52: "The gods in the Iliad are unaging, immortal, and far superior to mortals in knowledge and power. Everything they possess is correspondingly better: for example their clothing, armor and horses"; on the characteristics and functions of the gods cf. also EDWARDS 1987, 125-127.

58 Cf. Nilsson 1967-1974, I 368: "Ein hervorstehender Zug der homerischen Auffassung der Religion ist der Anthropomorphismus und der Rationalismus. Beide gehen Hand in Hand, sowohl die Götter wie auch ihr Wirken werden nach menschlichem Maß vorgestellt." Cf. also Idem 372: "Der Anthropomorphismus bei Homer ist nicht nur äußerlich, plastisch, sondern vor allem innerlich; die Götter handeln, wirken und gebärden sich wie die Menschen."; cf. also Kraus 1984, 19, who remarks on the "Menschenähnlichkeit der Götter", for: "Nicht nach ihrem Ebenbild haben die Götter die Menschen geschaffen, sie sind überhaupt nicht ihre Geschöpfe, sie sind vielmehr Geschwister der Götter."

59 Cf. Wüst 1958, 85: "Der homerische Gott zeigt also Tugenden und Laster, Vorzüge und Mängel wie der homerische Mensch, er ist ein auf eine exemplarische Stufe erhobener Mensch, ein 'Ausbund' von Mensch (in der ursprünglichen Bedeutung des Wortes Ausbund)."

60 Cf. SChWABL 1954, 59, who observes: "Wo sie (sc. die Götter) an Gleiche kommen oder in einen anderen als 
Even the ruler of the gods, Zeus, ${ }^{61}$ whose superiority over the other gods is indisputable, ${ }^{62}$ experiences the limits ${ }^{63}$ of his power and is so far removed from a central divine figure in the monotheistic sense ${ }^{64}$ (e.g. Christianity or Islam) that there would even be room for the simultaneous validity of a firm belief in a predetermining force of destiny. In the Iliad and the Odyssey, however, every plot development, with or without divine intervention, is solely rooted in the human actors involved. These humans act voluntarily and independently make one or the other various available alternative life choice. In a world like that, the gods have to have limits. ${ }^{65}$

\section{Man as the foundation for the development of the story of the Iliad}

I t has already been noted that the plan of Zeus, which allegedly occupies centre stage in the story, is in fact concerned only with fulfilling the request made by Thetis, who is acting on her son's behalf when she approaches Zeus and asks him for retribution. This plan is thus exclusively triggered by the motives and resultant actions of Achilles and tempered by his wrath. The divine plan is instigated by the blind wrath of this one man, who aims to highlight his importance as a warrior for the outcome of the siege of Troy by enlisting divine aid for the Trojans, while simultaneously taking revenge for his bruised ego and loss of face, primarily on Agamemnon, but also on all the other Achaians.

The plan does not always develop along the lines that Zeus had envisaged; ${ }^{66}$ in fact it even fails in the end, since it results not in the restoration of Achilles' honour, but in the death of his dear comrade Patroklos. This is the reason Achilles finally resumes the fight against the Trojans. However, the plan's failure is itself due to no other than Achilles himself, since he refuses to accept the offer of reconciliation made by the Achaian envoys in book 9 .

In Homer's narrative, the further development of the story of the Iliad is likewise princi-

den ihnen zustehenden Bereich, da sind auch sie am Ende: auch sie in all ihrer Übermacht sind nur Teile eines Ganzen und treffen so als Handelnde auf ihre Grenzen."

61 On the function of the gods in Homer cf. Schrade 1952, 118-134; Lloyd-Jones 1983, 1-54; Erbse 1986, 209-256.

62 Kraus 1984, 23, describes Zeus as follows: "Zeus steht zwar über den anderen Göttern, aber auch er ist noch zu nahe, auch er trägt den Charakter des Weltgeschehens an sich, wie es die Menschen tatsächlich erfahren, er ist launenhaft und beeinflussbar, hinter ihm erst wird die abstrakte Ordnung sichtbar, die er, im Widerstreit mit anderen Göttern und manchmal auch mit sich selbst, zu verwirklichen trachtet, die Moira oder Aisa, die er befragt, wenn es um die endgültige Entscheidung geht."

63 Cf. Pohlenz 1955, 5: "Aber allmächtiger Herr Himmels und der Erden ist selbst Zeus nicht, der Höchste der Himmlischen. Denn auch er steht ebenso wie die übrigen Götter innerhalb der Welt und ihrer Ordnung."

64 Cf. Adkins 1960, 13: "Zeus has no perfections: he merely possesses the qualities he does possess in a superlative degree."

65 Cf. Kraus 1984, 23: "Da konnte er (sc. Homer) gar keine anderen Götter brauchen”; ErbSE 1986, 299, believes that Homer needs the gods precisely because the humans in Iliad and Odyssey are not free in their actions: "Der epische Dichter benötigte die Götter, weil er von Menschen, die noch keine Freiheit des Handelns kannten, nur mit ihrer Hilfe erzählen konnte."; cf. also Idem 1990, 17: "Die Götter werden immer dort aktiv, wo die Menschen, würden sie aus eigener Initiative handeln, von den Zeitgenossen des Dichters nicht mehr verstanden werden könnten. [...] Sie sind die Helfer, an die sich der Epiker wendet, wenn er eine lückenlose Erzählung zustande bringen will."

66 Cf. Sarischoulis 2008a, 297. 
pally due to the motives, decisions, and resultant actions of the human actors involved. The following events take place without any form of divine influence or predetermination: The priest Chryses goes to the Achaian camp and pleads for the release of his daughter. Agamemnon refuses the ransom offered for Chryseis. Agamemnon returns Chryseis to her father, but demands that Achilles hand over Briseis as a replacement. Achilles gives up his gift of honour and withdraws from combat in anger. The Achaians accept the advice given by Nestor and assemble envoys, who make Achilles a very attractive offer. Achilles refuses the offer of reconciliation made by the presbeia. Despite the mounting Achaian losses, Achilles persists in his wrath and refuses to join in the fighting. Patroklos decides to fight the Trojans on his own and in Achilles' stead. Achilles does not stop him. Patroklos kills Sarpedon. Hector braves Achilles in single combat. Achilles kills Hector. Priamos goes to the Achaian ships without heeding the incredible danger he is putting himself in and pleads with Achilles for the return of his son's remains. Achilles complies with Priamos' request.

The humans alone, with their decisions and voluntary actions, thus determine the development of the story of the Iliad.

\section{Man as the foundation for the development of the story of the Odyssey}

$\tau$ t has already been noted that the decision of Odysseus to return home was made long before the beginning of the Odyssey and that the hero's great suffering stems from this deep desire being thwarted for so many years. This suffering then induces Athena to approach Zeus and plead with him to adopt the poor man's motivation and grant him aid. The readiness of Athena - and of the other gods, whom Zeus convinces - to support the suffering hero in his efforts is triggered by Odysseus himself, who, unlike Achilles in the Iliad, enlists this divine support for his plans without being aware of it. Only Poseidon, who seeks revenge on Odysseus for personal reasons, namely the blinding of his son Polyphemos, makes life difficult for him at every turn. What was valid for the Iliad thus also applies to the Odyssey: Divine action, Athena's and Poseidon's, is in both cases triggered solely by the motives and resultant actions of a human being.

In Homer's rendering, the further development of the story of the Odyssey can likewise be reduced to the motives, decisions and resultant deeds of the human actors. Without the interventions, divine and otherwise, the Odyssey thus presents the following events: Odysseus is determined to return home. Odysseus and his comrades manage to free themselves from the cave of man-eating Polyphemos. Out of sheer curiosity, Odysseus' comrades open the magical bag of wind given Odysseus by Aiolos. Afterwards, Odysseus and his comrades spend a whole year with Kirke and travel to the underworld to seek Teiresias' advice. Odysseus' comrades slaughter and consume the cattle of Helios. Alkinoos and the Phaeacians decide to offer Odysseus an escort home. On Ithaca, the suitors behave sinfully for three years. Eumaios and Eurykleia stay loyal to Odysseus, whereas Melanthios does not. Penelope remains true to her husband for 20 years. Odysseus and Telemachos kill the suitors, but let Phemios and Medon live.

The humans, who make decisions and act of their own volition, thus determine the development of the action in the Odyssey. 


\section{The foundation of Homer's narrative (mode): The motivations of the acting characters}

M otivation as a prerequisite for action plays an important part in Homer's narratives. The motives of any given actor are invariably brought to the fore, irrespective of whether the actor is a human or a god. The corner stone of the Homeric narrative (mode) is that the respective acting human or divine character individually determines the motives underlying his actions. Whether the current or future actor, human or divine, arrives at these action-inducing motives alone or whether he is made aware of them by another human or divine figure is often part of the narrative, but is of only secondary importance for the evaluation of the actual action.

The fact that the development of the action in both Iliad and Odyssey is so obviously, emphatically, and systematically due to the idiosyncratic motives of human and divine figures with independent thoughts and self-determined actions must necessarily mean that the poet of the Homeric epics consciously selected this narrative mode. It is evidently rooted in Homer's personal world view, which may have been one among many in his time, but is very likely to have been generally valid. It may well be an important reason as to why Iliad and Odyssey were popular already with their original audiences.

The basic principles of Homer's narrative mode can be described as follows: at any point in time, the action can potentially develop in any direction imaginable. Homer does not treat the development of the action, which was prescribed by an already well-established and generally known tradition, as (pre)determined by unalterable fate or omnipotent gods, but rather ties it to the idiosyncratic motives, as well as the resultant decisions and actions of freely acting characters.

Homer understands not only the humans, but also the gods as acting characters that make decisions of their own volition, choose the motives of their actions, and thus act independently. Individual attitudes, as well as personal aims and desires, which are based in turn on the inner substance and individual potential of each human and divine actor, thus determine the process of selecting these self-determined motives and the resultant actions of humans and gods.

When a god and a human encounter one another in Homer's narrative, they both remain independent actors. The same applies to encounters between humans and among gods: Even in conjunction, the characters continue to act self-sufficiently and independently of one another. If there is conflict between a human and a god, the weaker human is confronted with the unpleasant consequences of his decision not to avoid the conflict. The same result applies to conflicts between two humans or two gods: the weaker party that decided in favour of the conflict has to bear the negative consequences of this decision. If a god helps a human or a god, or if a human helps another human in an undertaking, this entails that the helper decides to accept the motives of the partner and acts accordingly.

Homer is also very intent on describing the motives of acting characters in very precise detail, even though this is naturally not always possible. Homer and his acting characters distinguish between motives that are the result of their own deliberations and those that are the result of external influence by another human or god. Guided by idiosyncratic motives, aims or desires, every human and every god is potentially capable of alerting any human, and also any god, to motives that then trigger the desired action by the other party.

But this knowledge is completely without consequence for the ascription of responsibility: every human or divine actor is solely responsible for his own actions, irrespective of whether 
he arrived at the underlying motives alone or through the guidance of another human or god. From a Homeric perspective, the human or divine actor decided to accept these particular motives freely; in the Homeric narratives, this decision - and all others - is the achievement of the respective actor alone.

As a result, the superiority of gods over humans does not mean that human processes of deliberation and decision-making are under their authoritarian control, nor that human action is determined by divine intervention or the actions of individual deities. If a god wants to deceive a human or influence his behaviour, he thus does nothing more than alert him to "fitting" motives that appeal to his inner self and basic character and induce him to act in the desired way. Also in this case, the responsibility for accepting or refusing the proffered motives lies with the human being alone.

In this regard, appeals to divine interference as the cause of an action constitute not a generally accepted explanation, but a fleeting and transparent excuse, uttered when the actor himself, one of his contemporaries, or even Homer himself is not capable or ready to offer a more in-depth explanation of the motives behind the action. Not even the speaker himself honestly believes that he can excuse the action, let alone exculpate himself as the actor. In addition, appeals to divine intervention or participation are part of a narrative motif that serves to emphasize the exceptional quality of the action in question, even without actual divine involvement.

It has emerged that the basic principle of Homeric narrative lies in determining the idiosyncratic motives that produce the actions of autonomous humans and gods. The Homeric epics present motivation in the following way:

A human, a god or Homer himself gives an account of the motives that led to an action, while taking care to be as objective as possible by adducing all the information and knowledge available to him. One can even observe that the human or god in question did not arrive at the motives behind his actions on his own, but that another human or god offered him his own motives in pursuit of his own aims, or even invented "fitting" motives specific to the needs of the situation. In both cases, the actor bears full responsibility for his deeds since he voluntarily adopted the motives that underpinned his actions.

Even without tangible divine interference, a human, a god, or even Homer himself may attribute the motives that lead to an action to a deity. This occurs in the following three scenarios:

a) When the actor's responsibility is to be shifted to the gods;

b) When the actor's actual motives are to remain unclear or the background of the deed is to be described in an ephemeral and non-committal fashion;

c) When the exceptional quality, great significance, or immense difficulty (etc.) of the deed is to be highlighted by referencing divine participation, or when the actor wishes to lay claim to divine assistance.

One can observe that the human actor, who autonomously determines the motives of his own actions, invariably occupies centre stage in the narrative, since he is responsible for his own actions, as well as for the development of the actions triggered by his agency. 


\section{The narrative mode of Iliad and Odyssey}

I $\mathrm{n}$ the development of the story of Iliad and Odyssey, the outcome of certain key events is undoubtedly predetermined. These events are not, however, determined by a diegetic power of fate, but rather exist as established facts in the epic tradition and include, e.g., the death of Achilles at Troy, the subsequent fall of the city, and Odysseus' return home. This knowledge is not based on an existing belief in fate, which holds that the future is predetermined, but rather on a conception of a retrospectively fixed past. The acting characters of the two epics do not yet possess this knowledge, which is exclusive to those who live later, including Homer and his first contemporary audience.

Within Homer's narrative, the outcomes of certain actions are therefore fixed because they are known to the poet and his audience. Homer's elaboration of these established events reveals his personal attitudes and world view: While he could potentially have attributed their predetermined outcomes to destiny or divine predestination, he did not do so. The world of Iliad and Odyssey does not contain any predetermined events; instead there are certain retrospectively established facts that Homer consciously portrays as products of a freely developing narrative. The fact that these epic narratives ascribe the established outcome of certain actions to the idiosyncratic motives of characters, who are themselves portrayed as making their own decisions and performing the resultant actions, must therefore be attributed to Homer's personal choice.

Not fate or divine omnipotence, but independently acting characters, both human and divine, who select their own motives for their actions, determine the sequence of events in the Homeric epics. Homer never relates the events of his narrative to the coercive powers of predetermining and omnipotent forces, but treats them as the result or consequence of actions undertaken by characters that are masters of their own agency.

This narrative mode most probably derives from Homer's personal view, not wanting to reduce his creations to simple puppets. On the one hand, it is beyond doubt that the characters that populate Homer's works are fictional and hence cannot be anything but "clueless" and "unaware" poetic creations, solely dependent on his knowledge. Their decisions and deeds necessarily have to confirm the outcome prefigured by tradition, which Homer's composition cannot possibly contradict.

On the other hand, Homer's exceptional poetic ability allowed him to bring these artificial creations, limited by the established confines of epic tradition, to life as "real" humans equipped with a sense of responsibility, independent cognitive faculties, and idiosyncratic aims that enable them to choose their motives themselves, make their own decisions, and develop their agency accordingly. Despite the epic tradition, which prescribes the course of certain events, this narrative mode enabled Homer to build his story around "real", lively, freely developing strands of action; the possibility that any strand might potentially diverge from the epic tradition thus emerges as an important aspect of Homeric narrative.

This phenomenal achievement in conveying the story of both epics is most probably rooted in Homer's personal world view. If Homer had himself believed in preordained destiny, he would not be so consistent in expounding the motives of his characters in his narrative, nor would he treat them as the causes that underlie the twists and turns of the action. The poet does not believe in "fate" and thus nor do his characters.

Homer evidently considers himself to be the sole determinant of his motives, and accordingly the characters portrayed in his epics also determine their own motives and are hence 
in control of their own actions. Homer is aware of his freedom, as well as his characteristics as an individual; as a consequence, he grants his freely and individually moulded characters an awareness of their freedom of action, a quality that he himself possesses. Hence his characters are also aware of their freedom and the resultant responsibilities; in addition, they are aware that their individual characteristics fundamentally distinguish them from other characters.

This does not mean to say that Homer does not frequently remind us that the outcome of specific events is predetermined by epic tradition - especially when he would have preferred a different turn of events; but he roots the actions that led to this outcome in idiosyncratic motives and the conscious and independent decisions of freely acting humans and gods. The selection of motives is consistently emphasized not as an emphatic nod to destiny, but as an unequivocal result of internal processes that are dominated by the actor's essence, individual characteristics, and current aims and desires. In this way, Homer's narrative continually notes the freedom of the human actors, which even the undeniable superiority of the gods cannot limit. The narrative mode of Iliad and Odyssey thus reflects the way in which Homer's personal world view interprets the sequence of events surrounding the Trojan War and the return of the surviving Greek warriors, which was widely known from the established epic tradition.

Just like the humans, the gods too are Homer's creations, not "real" gods, but freely invented divine characters. They are superior to the humans but nevertheless remain very similar throughout. Homer's narrative portrays them as acting characters along the same lines and shows them deliberating the best course of action, choosing their own motives based on their own aims and desires, and making the appropriate decisions, which serve as a basis for their independent actions. Furthermore, they are also bound by the facts known from the epic tradition, which they have to confirm by their aims, decisions, and resultant actions. As with the humans, Homer managed to create independently acting characters also on the divine level, whose independent actions cannot of course contradict established tradition.

Homer's narrative mode is exclusively based on the freedom of decision and action enjoyed by the acting characters of his epics. This basic principle of his narrative style means that he can, or at least aims to, preserve the freedom of his acting characters as unlimited, while simultaneously incorporating the widely known tradition of his time. For this reason, Homer has given the gods an important task: Whenever a plausible turn of events or possible plot development contradicts the facts known from the epic tradition, but might still be adopted due to the freedom of action enjoyed by the characters, a god is made to employ his individual characteristics or even superiority to prevent this from happening. Even in this case, however, the divine action is linked to motives chosen solely by the acting god, as well as the resultant decisions. Hence the action stems from the god's free will. In this respect, these situations are thus resolved by the poet's knowledge being synchronized with the will of gods, especially with that of Zeus.

The freedom of the actor as the sole determining factor for narrative development therefore emerges as the indisputable corner stone of Homer's narrative mode. Even pre-established facts are not ascribed to preordained and inevitable destiny, but tied to the free will of independently acting gods, who freely choose the motives of their actions.

Efstratios Sarischoulis

Democritus University of Thrace Apolloniados 48

GR - 54632 Thessaloniki Meereslicht@gmx.de 


\section{Bibliography}

ADKINS 1960

A. W. H. Adkins, Merit and Responsibility, Oxford 1960.

AdKINS 1970

A. W. H. Adkins, From the Many to the One: A Study of Personality and Views of Human Nature in the Context of Ancient Greek Society, Values and Beliefs, London 1970.

BIANCHI 1953

U. Bianchi, $\triangle I O \sum A I \Sigma A$, Destino, Uomini e Divinità nell'Epos, nelle Teogonie e nel Culto dei Greci, Roma 1953.

Burkert 1998

W. Burkert, Kulte des Altertums: biologische Grundlagen der Religion, München 1998.

Chantraine 1968

P. Chantraine, Dictionnaire étymologique de la langue grecque. Histoire des mots, Paris 1968 [1984].

DieTRICH 1965

B. C. Dietrich, Death, Fate and the Gods: The development of a religious idea in Greek popular belief and in Homer, London 1965.

EBERHARD 1923

P. E. Eberhard, Das Schicksal als poetische Idee, Paderborn 1923.

EDWARDS 1987

M. W. Edwards, Homer, Poet of the Iliad, Baltimore 1987.

ENGEL 1926

W. Engel, Die Schicksalsidee im Altertum, Erlangen 1926.

ERBse 1986

H. Erbse, Untersuchungen zur Funktion der Götter im homerischen Epos, Berlin 1986.

ERBSE I 990

H. Erbse, «Nachlese zur homerischen Psychologie», Hermes 118 (1990), 1-17.

FRÄNKEL 1962

H. Fränkel, Dichtung und Philosophie des frühen Griechentums, München 19622.

FRISK 1960-70

H. Frisk, Griechisches Etymologisches Wörterbuch III, Heidelberg 1960-70 [I: Fasc. 1-10, Heidelberg 1960, II: Fasc. 11-16, Heidelberg 1961-65].

Greene 1944

W. C. Greene, Moira, Fate, Good and Evil in Greek Thought, New York 1944.
Kraus 1984

W. Kraus, "Götter und Menschen bei Homer", in Id., Aus Allem Eines: Studien zur antiken Geistesgeschichte, Heidelberg 1984, 15-27 (Erstdruck: Wiener Humanistische Blätter 18 [1976] 20-32).

Krause 1936

W. Krause, «Die Ausdrücke für das Schicksal bei Homer», Glotta 25 (1936), 143-152.

Krause 1949

W. Krause, "Zeus und Moira bei Homer», Wiener Studien 64 (1949), 10-52.

Kullmann 1956

W. Kullmann, Das Wirken der Götter in der Ilias. Untersuchungen zur Frage der Entstehung des homerischen „Götterapparats“, Berlin 1956.

LfgrE 1955

B. Snell, U. Fleischer, H. J. Mette, Lexikon des frühgriechischen Epos, Göttingen 1955, begründet von B. Snell, fortgesetzt von H. Erbse.

LEITZKe 1930

E. Leitzke, Moira und Gottheit im alten griechischen Epos: Sprachliche Untersuchungen, Göttingen 1930.

LEJEUNE 1972

M. Lejeune, Phonétique historique du Mycénien et $d u$ Grec ancien, (Tradition de l'Humanisme 9), Paris 1972.

LESKY 1961

A. Lesky, Göttliche und menschliche Motivation im homerischen Epos, Heidelberg 1961.

LLOYD-JoNES 1983

H. Lloyd-Jones, The Justice of Zeus, Los Angeles ${ }^{2}$ 1983.

LUTHER 1954

W. Luther, Weltansicht und Geistesleben, Göttingen 1954.

Morrison 1997

J. V. Morrison, "Kerostasia, the Dictates of Fate, and the Will of Zeus in the Iliad", Arethusa 30/2 (1997), 273-296.

NiLsson 1967-1974

M. P. Nilsson, Geschichte der griechischen Religion (Handbuch der Altertumswissenschaften V 2) I-II, München ${ }^{3}$ 1967-1974.

Отто 1947

W. F. Otto, Die Götter Griechenlands, Frankfurt am Main $^{3} 1947$. 
Palmer 1980

L. R. Palmer, The Greek Language, Cambridge 1980.

Peters 1980

M. Peters, Untersuchungen zur Vertretung der indogermanischen Laryngale im Griechischen, Vienna 1980.

Pirenne-Delforge \& Pironti 2011

V. Pirenne-Delforge \& G. Pironti, «Les Moires entre la naissance et la mort: de la représentation au culte», Études de lettres 3-4 (2011), 93-114 (http://edl. revues.org/143).

PÖTsCher 1960

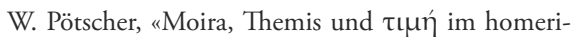
schen Denken", Wiener Studien 73 (1960), 5-39.

Pohlenz 1955

M. Pohlenz, Griechische Freiheit: Wesen und Werden eines Lebensideals, Heidelberg 1955.

SARISCHOUlis 2008a

E. Sarischoulis, Schicksal, Götter und Handlungsfreiheit in den Epen Homers, Stuttgart 2008.

SARISCHOULIS $2008 \mathrm{~b}$

E. Sarischoulis, Motive und Handlung bei Homer, Göttingen 2008.

SARISCHOULIS 2008c

E. Sarischoulis, 85 Jahre Forschung zu Schicksalsbegriffen, Göttern und Selbstverständnis bei Homer: eine Synopse, Frankfurt am Main 2008.

SARISCHOULIS 2009

E. Sarischoulis, "Zur Etymologie und Bedeutung

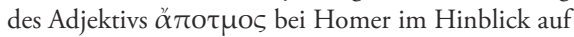
potentiell bedeutungsverwandte Begriffe», Philologus 153/1 (2009), 3-9.

SARISCHOULIS 2014

E. Sarischoulis, «Hybris in den Epen Homers: Der feststehende Ausgang der Vorbestimmung des Schicksals und des Planens der Götter oder das Ergebnis der individuellen Absicht und des freien Willens?», in M. Christopoulos, M. Paizi-Apostolopoulou (ed.), Crime and Punishment in Homeric and Archaic Epic, Proceedings of the 12th International Symposium on the Odyssey, Ithaca 2014, 57-80.

SCHADEWALDT 1965

W. Schadewaldt, Von Homers Welt und Werk, Stuttgart $^{3} 1965$.
SCHADEWALDT 1966

W. Schadewaldt, Iliasstudien, Darmstadt $1966^{3}$.

SCHEIN 1984

S. Schein, The Mortal Hero. An Introduction to Homer's Iliad, Berkeley 1984.

Sснмітт 1990

A. Schmitt, Selbständigkeit und Abhängigkeit menschlichen Handelns bei Homer. Hermeneutische Untersuchungen zur Psychologie Homers, Stuttgart 1990.

SCHRADE 1952

H. Schrade, Götter und Menschen Homers, Stuttgart 1952.

SCHWABL 1954

H. Schwabl, «Zur Selbständigkeit des Menschen bei Homer», Wiener Studien 67 (1954), 46-64.

SNeLl 1928

B. Snell, Aischylos und das Handeln in Drama (Philologus Suppl. XX/1), 1928.

SNELL 1975

B. Snell, Die Entdeckung des Geistes, Göttingen ${ }^{4}$ 1975.

STOCKINGER 1959

H. Stockinger, Die Vorzeichen im homerischen Epos: Ihre Typik und ihre Bedeutung, St. Ottilien Oberbayern 1959.

VoIGT 1934

C. Voigt, Überlegung und Entscheidung: Studien zur Selbstauffassung des Menschen bei Homer, Berlin 1934 [1972].

Wilamowitz-MoellendorfF 1956

U. v. Wilamowitz-Moellendorff, Der Glaube der Hellenen I-II, Basel 1956.

WOLFF 1929

E. Wolff, "Rezension zu Snell: Aischylos und das Handeln im Drama», Gnomon 5 (1929), 386-400.

WüsT 1958

E. Wüst, "Von den Anfängen des Problems der Willensfreiheit», Rheinisches Museum 101 (1958), 75-91. 